\title{
Practice of Outsourcing for Strategic Purposes by Russian and Foreign Companies
}

\author{
M.V. Klimovets \\ Head of Development of the Department of Finance and Banking, \\ The Russian Presidential Academy of National Economy and Public Administration, Moscow, Russia \\ Email:m.klimovets@mail.ru
}

\section{Doi:10.5901/mjss.2015.v6n3s6p193}

\section{Abstract}

Increasing competition in Russian business environment under the conditions of import substitution and sanctions led to significant complication of managerial decision-making. The main target of financial managers is to contribute to corporate competitiveness. Development of new competitive strategies requires the search for new methods of improvement of business process efficiency. Research of the methods used by foreign companies to develop and enhance competitive advantage reveals that financial outsourcing is one of the commonly accepted instruments of corporate strategy implementation. The increased focus of Russian companies on outsourcing as well as the development of outsourcing services in Russia under the lack of information, related to the issue, makes the subject of this article relevant to the current situation. The purpose of the research is to analyze the efficiency of financial outsourcing as a method of corporate strategy implementation.

Keywords: outsourcing, efficiency, international business, outsourcer, strategic management, international company, business functions.

\section{Introduction}

During the turbulent period of global economy, volatility of prices in the world markets, and strengthening of competition, the use of financial outsourcing allows reducing expenses and concentrating on development of business. In many countries, which already have the strategies for overcoming economic crises, external accounting is a norm for most organizations (Avdokushin, 2007). Analyzing the experience of foreign companies and the development of institute of outsourcing abroad and comparing them to the process of formation of outsourcing model in Russia, it is possible to allocate a variety of tendencies of outsourcing development in the coming years.

In the 1990s there began a period of increased interest for outsourcing of business processes, and beginning from 2000 there has been a significant rise of demand for services of outsourcing companies.

Table 1. Global expenses for outsourcing, USD billion ( Klimovets, 2010 )

\begin{tabular}{|l|c|c|c|c|c|}
\hline & 2000 & 2005 & 2010 & 2012 & 2014 \\
\hline Outsourcing of business processes & 80.04 & 86.35 & 91.35 & 100.59 & 111.30 \\
\hline Outsourcing in IT sphere & 144.18 & 157.32 & 161.01 & 175.15 & 191.62 \\
\hline Total volume & 224.21 & 243.67 & 252.37 & 275.74 & 302.91 \\
\hline
\end{tabular}

According to the British company LogicaCM, the companies' expenses for outsourcing constituted approx. USD 140 billion in 2006, and they will reach USD 220 billion by 2015 (Klimovets, 2015).

\section{Methods and Materials}

In the global market of outsourcing of business processes, there are already formed segments which conform to clients' needs in one or another type of services. For example, there are just a few companies in the segment of payroll preparation, while the segment of accounting services and consulting includes several hundreds of them. It is difficult to divide Western companies as to the character of services provided - even the players that initially specialized on the work in the IT sphere now provide a whole range of services. However, all service providers may be conventionally divided into groups depending on the range of provided services. 
Table 2. Segmentation of providers of outsourcing services (Avdokushin, 2005)

\begin{tabular}{|c|c|}
\hline Complex approach & $\begin{array}{l}\text { Full range of services globally } \\
\text { Accenture, CSC, EDS, IBM Global Services } \\
\text { Full range of services in many countries } \\
\text { ACS, CGE\&E, CGI, Fujitsu, HP, Lockheed Martin, NorthropGrumman, Perot Systems, } \\
\text { SAIC, SBS, SchlumbergerSema, Unisys }\end{array}$ \\
\hline Specialized approach & $\begin{array}{l}\text { Consultants/integrators, specialists } \\
\text { AMS, BearingPoint, Ciber, CTG, Deloitte, Keane }\end{array}$ \\
\hline Low cost alternatives & $\begin{array}{l}\text { Services in other countries } \\
\text { Birlasoft, Cognizant, Covansys, EPAM, Exigen, Hexaware, HCLT, I-Flex, Infosys, } \\
\text { Intelligroup, iGate, Luxsoft, Mastek, Mphasis, Patni, Reksoft, Satyam, Softtek, Syntel, } \\
\text { TCS, Wipro }\end{array}$ \\
\hline $\begin{array}{l}\text { Applications support, narrow } \\
\text { specialization, or vertical markets }\end{array}$ & $\begin{array}{l}\text { Providers for support for applications that work on the level of enterprises } \\
\text { BlueStar, Corio, Usi, NetLedger, Salesforce.com, Trizetto, Upshot }\end{array}$ \\
\hline Software as a service & $\frac{\text { Independent sellers of software }}{\text { PeopleSoft, Oracle, SAP }}$ \\
\hline
\end{tabular}

At the end of 1990s, the companies fully evaluated the advantages of the model of outsourcing. According to research by Yankelovich Partners, conducted in 14 countries of the world among 304 representatives of top-management, 63\% of respondents confirmed that they passed to contractors one or several non-profile functions. Among those that performed outsourcing, $84 \%$ had positive attitude and stated that they were satisfied with the work of outsourcing companies. Nowadays, a lot of companies transfer their non-profile activities to outsourcers. According to various estimates, about $60 \%$ of the US companies use the services of professional contractors, while in Europe this number is $45 \%$ (Klimovets, 2006).

\section{Results}

All potential consumers of services of financial outsourcing may be divided into two groups, as to the quantity (regardless of the sphere). Outsourcing is profitable for small companies (up to 150-200 employees) or for large organizations (more than 1,000 employees). Small companies do not have funds for development and support for infrastructure, and large companies try to avoid expansion of non-profile departments.

Financial structures have been one of the main consumers of outsourcing services. Continuity of business processes is very important for banks: cost of a lost hour for bank can be measured in hundreds of thousands dollars. Besides, it is one of the most competitive zones, in which the reduction of business profitability takes place. The most active sphere that features the most ambitious plans for financial outsourcing is bank retail, which leads to increase of branch network. Creation of a network requires new employees and a single informational infrastructure, and increases the document flow. All of this makes banks search for ways of wages reduction, which can be helped by outsourcing companies (Klimovets, 2014).

A vivid example of successful realization of outsourcing project in Russia is cooperation of Small Business Financing Bank (KMB BANK) and Intercomp. company. KMB BANK is one of the leaders in the sphere of financing and providing bank services for private entrepreneurs, as well as for small and medium Russian enterprises. KMB BANK has a branched network of offices on the territory of 25 Russian regions with more than 1,700 employees (Klimovets, 2014).

The bank had to create and support automatic system of payroll preparation, without increasing the quantity of employees. In order to realize that project, the bank planned to involve an outside agency for payroll preparation and creation of centralized database of personnel accounting; that had to be an organization which had already recommended itself as a market expert in the sphere of financial outsourcing and HR management. In January 2003, the decision was made to pass the payroll preparation and technical support of HR database to Intercomp. The company was able to offer a comprehensive, flexible, and economically rational (as to quality/price ratio) solution. The main factor was a complex nature of Intercomp's solutions: software products, in which the unique methodical and technological basis of Intercomp was built, allowed, on the one hand, performing quick audit of employees' personnel files, implementing a centralized personnel account of regional bank departments, and creating and organizing support for centralized database for personnel. On the other hand - fully automatizing the process of payroll preparation, including creation of report information, data entry, and technical support.

The process of payroll preparation was fully optimized, and a centralized system for HR account and support was 
created - without involving additional resources (creation of technical base, development of methodology, increase of personnel quantity). Intercomp employees are always ready to provide informational and technical support to the bank, tracking all changes in the Russian legal system and providing expert consultations regarding issues of accounting and taxation.

KMB BANK is a vivid but not the only example of outsourcing for payroll preparation in Russia. Transferring financial functions for outside performer begins from outsourcing of payroll preparation. This business process is not usually a source of competitive advantages, and its transfer does not lead to loss of control of business and to reduction of control level, while transfer of other business processes may lead to huge risks. Practice of using outsourcing abroad shows that companies which successfully transferred the payroll preparation to a company-outsourcer, are inclined to gradual outsource of other components of financial function with their acquisition of necessary experience (Figure 1).

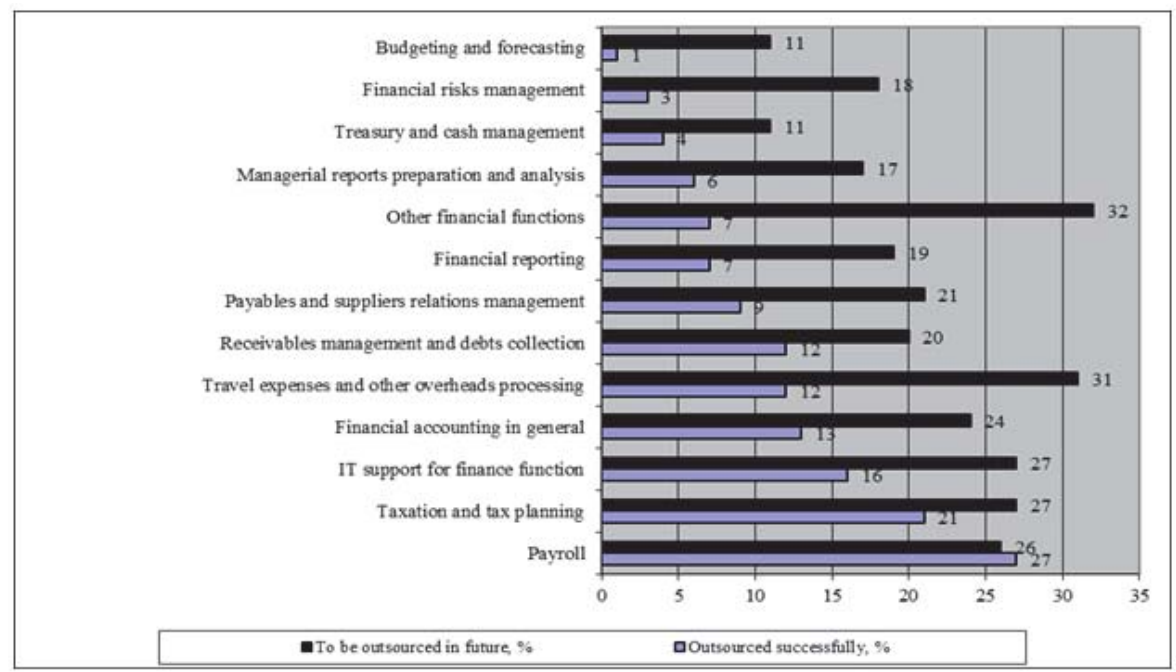

Fig.1 Functions outsourced to outside performers and functions to be outsourced in future (Klimovets \& Fundy, 2014)

The above diagram shows that managers of financial departments leave strategic and analytical processes within the company, while outsourcing the spheres, in which providers are able to perform reorganization of processes at low costs.

Competition in the developed markets of outsourcing makes providers conform to the highest professional requirements, so managers of companies-clients can trust outsourcer with tasks that have strategic value, without serious consequences for business. Development of outsourcing market in Russia and acquisition of valuable experience of building partnership relations with providers will allow managers to use the possibilities of outsourcing as fully, as their foreign colleagues do.

The largest oil company in the world, British Petroleum, first gave to outsourcing the accounting of its extracting activity in Europe 15 years ago, negotiating an unprecedented deal for USD 20 million per year. By 2012, outsourcing of financial operations and accounting was implemented in other departments of the company worldwide. Two largest outsourcing companies, Accenture and IBM, were chosen as providers of services. The total cost of contracts constituted USD 1.5 billion per year (Klimovets \& Fundy, 2014). Specialists of BP mark an annual reduction of expenses during 13 years of use of outsourcing model. In whole, expenses for performing financial functions reduced by two times.

The outsourced processes include general accounting, accounting of joint ventures, retail operations, inventories, accounting of credit debts, and preparation of reports on management of financial activities (Klimovets, 2013). Though $\mathrm{BP}$, having outsourced a lot of processes, expanded the usual limits of outsourcing, it still holds true to the idea that analysis and decision making should remain within the company.

Annually more and more companies appear which are ready to outsource more and more of their functions. The scale of expansion of outsourcing of finances and its influence on business change very quickly. As a result, large foreign companies that have a huge experience in usage of providers' services, participate in formation of two tendencies in the sphere of financial outsourcing - transition from operations processing to outsourcing of strategic business processes and transfer of several processes to one provider for achievement of synergetic effect.

Organizations start to view outsourcing not only as operative lever for reduction of expenses but as strategic tool 
for acquisition and support for competitive advantages. Only 35\% of companies limit themselves to outsourcing of processes that have a low strategic value; $65 \%$ of companies outsource processes that have medium and high strategic value (Klimovets O.V. \& Klimovets M.V., 2013).

About $95 \%$ of expenses within outsourcing belong to discrete processes, like invoicing or payroll preparation. However, $61 \%$ of companies use one provider for implementation of many processes, which improves the relations and integration.

Russia quickly adopts foreign experience of outsourcing and, as to the rate of growth of the number of enterprises that use services of outside agencies, Russia is ahead of foreign countries. In view of surpassing rates of growth of outsourcing market in Russia (80\% per year), as compared to the global indicators, its volume will reach USD 4 billion by 2018 (Klimovets, 2010).

In the Russian market, the outsourcing services are implemented mostly by the Western countries, which have a huge experience in this sphere. The main players in the segment of financial outsourcing are Intercomp, BDO "Unikon Biznes Servis", and audit companies of the "Big Four". At that, Intercomp is the only large company in Russia for which provision of outsourcing services became the main type of activities. The more active development of this business by companies of the audit and consulting sphere is hindered by a following fact: according to the US law (Sarbanes-Oxley Act), which reaches also the subsidiaries of American companies abroad, the auditing requires an outside auditor. Thus, one company cannot prepare the reporting for the client and then confirm it. Due to this, the companies of the big four concentrate on services of preparing tax declarations and rendering them to tax authorities.

In recent years, outsourcing in the sphere of finances and HR administering has become more and more popular business technology among Russian managers. Contracts for outsourcing accounting and HR record management are signed for extended periods. At the same time, outsourcing of such business processes as logistics, marketing, and advertising is implemented in the form of separate projects.

There are several factors which directly or indirectly influence the process of development of financial outsourcing.

Table 3. Factors influencing the development of financial outsourcing

\begin{tabular}{|l|l|}
\hline Factors facilitating the development & Factors restraining the development \\
\hline Placement of Russian companies' shares in international financial markets & Insufficiently developed normative base \\
Transition to IFRS (International Financial Reporting Standards) & Insufficient managers' awareness of outsourcing possibilities \\
Active implementation of ERP-systems & Managers' mindset \\
$\begin{array}{l}\text { Strengthening of control from the state } \\
\text { Growth of outsourcers' professionalism }\end{array}$ & Lack of centralized business processes \\
Growth of the number of officially shown salaries & Insufficient development of professional liability insurance \\
& Low interest in financial outsourcing from small business \\
\hline
\end{tabular}

Note: ERP (Enterprise Resource Planning) is a system of planning and managing enterprise's resources which are necessary for sales, procurements, and accounting during fulfillment of customers' orders in the spheres of production, distribution, and services

In the last few years, the striving of Russian organizations for business transparency, caused by the companies' membership in IPO, became an important factor of outsourcing development. In Russia, there is a tendency of abandoning quasi-legal business schemes and dividing accounting into official and unofficial. A company that prepares for the entry into international capital market uses the independent external accounting as a declaration of intentions to build a transparent financial scheme.

Another factor, which can become one of the key stimuli for implementing outsourcing in all spheres of economy, is transition to international standards of financial reporting. International standards reporting is required from banks and companies, the shares of which are traded on stock exchange. However, these requirements will relate to all open joint stock companies. A lot of qualified accountants will be required. Lack of human resources is observed already, and the new law may become an impulse for the development of the Russian market of finances outsourcing. A lot of chief accountants of the Russian enterprises do not have enough experience and knowledge in the sphere of IFRS, so they already seek help from providers of financial outsourcing services (Klimovets, 2014).

In the last 10 years, when the Russian companies have been actively implementing ERP-systems, representatives of outsourcing companies mark the increased interest in their services from such clients. The final stage of implementing ERP-system is integration of modules of wages and HR, which, as a rule require substantial investments in the process of building ERP-system and then constant expenses for the support. At that moment financial managers are in doubt, whether it is worth investing huge funds into them or consider the option of outsourcing them.

Strengthened control for companies' activities from the state may be included to the list of factors that have positive 
impact on the development of outsourcing. Up to recent time, a lot of companies, using the drawbacks in the work of Russian tax authorities, were not responsible enough in the matter of accounting and tax reporting. With the change of situation in the sphere of control, there is a growing demand for the service of renewal of accounting, which many outsourcing companies offer their clients.

Growth of professionalism of services providers, which work in the Russian market, leads to increase of trust to outsourcing among financial managers. The first "stories of success" are a signal for transferring non-profile functions to outside performers. Managers of outsourcing companies mark that even as of now they have at their disposal a lot of highly qualified employees and possess enough experience in order to offer their clients completely new solutions in the sphere of finances outsourcing, like, for example, remote data entry through protected connection channels or preparation for IPO at the expense of an outsourcer.

The most popular outsourcing object among Russian companies is payroll preparation. Several years ago the development of this type of financial outsourcing was restrained by the fact that most of the Russian population received hidden wages (only $15 \%$ of 50 million people received official wages in 2004), while any outsourcing company works with official wages only. Nowadays, the situation changes for the better. $85 \%$ of the population receive official wages (according to the data of Russian Center for Research of Public Opinion), which significantly expands the possibilities for outsourcing use.

Together with factors that have a favorable impact on the development of outsourcing, there are obstacles for expansion of this effective method of activity optimization.

Primarily, these factors include low elaboration of legal base. Lack of appropriate laws already showed a harmful influence on the outsourcing at the beginning of 1990s, when large Western companies which began their work in the Russian market as suppliers of top-services for accounting had to switch to audit due to obscurity of legal consequences. Despite the guarantees which are provided for clients by outsourcing companies, a lot of managers are afraid to pass the accounting to outside agencies.

One of the strongest restraining factors is managers' lack of clear idea of outsourcing and its advantages over traditional methods of accounting. Some are intimidated by additional need for resources and funs during the transition stage and by a psychological barrier, related to transfer of accounting into "strange" hands (Klimovets, 2014). Most of the managers associate financial outsourcing with a threat of information leak. Many companies not only care about information confidentiality but are not interested in any openness, as very often accounting has a quasi-legal character.

Subjective factors also include the specifics of Russian managers' mindset and their wish to concentrate their company around one person or a certain managing group and lack of trust to business partners. The peculiarity of Russian business is a strong vertical integration of enterprises and cooperation of old-fashioned productions. Under conditions of emerging Russian economy, the gradually developing services market leads to reduction of need of large enterprises for a wide range of their own production, supplemental, and functional departments. Fear of changes makes the managers of these industrial groups abandon the independent performance of certain functions. Very often they try to solve their problems by turning supplementary departments into subsidiary enterprises, which perform "internal" outsourcing of some functions within the group. Experience of developed countries shows that this strategy leads the company to either final transition to outsourcing, or reduction of its efficiency in whole due to additional expenses for creation of management apparatus for subsidiary enterprises and due to complexity of managing huge structures.

Another reason for refusal from outsourcing, caused by practice of doing business in Russia, is lack of standardized business processes. Very often the companies' managers are sure that their business' structure is very complicated, so only the internal accounting is able to work with other business processes on a high level. This situation is most often seen in companies which do not have clearly structured and formalized business processes. Use of outsourcer's services brings the hidden problems to the surface and allows determining the reserves for efficiency growth.

Nowadays, the Russian market of financial outsourcing is characterized by growing demand for large projects. Any such project is connected with certain risks and, consequently, requires insurance. Besides, liability insurance market is at a low stage of development in Russia. Practice of developed markets supposes the liability insurance policy for large companies. It is not an obligation, but serious players of outsourcing market think that this policy is an important condition for doing business in a civilized manner. The system of outsourcers' insurance develops at the expense of Russian branches of Western companies which consider the liability insurance policy a necessary condition for an outsourcer.

There is a certain economic aspect which makes a lot of outsourcing companies abandon the idea of purchasing professional liability insurance policy. Insurance coverage which can compensate all possible damages of a client is rather expensive, so the cost of insured company's services grows. If an outsourcer has such insurance, it automatically supposes the increase of services costs by $7-10 \%$. At the same time, the companies that do not have insurance can keep 
the cost of their services on the acceptable level (Klimovets, 2015).

Despite all obstacles, there emerge new outsourcers in the Russian market which insure their professional liability. For example, Intercomp insured professional risks, related to wrong calculations, in Russian National Insurance Society. Insurance coverage reaches USD 500,000, but Intercomp has never used this policy of insurance.

In the sphere of small entrepreneurship, which suffers from lack of financial resources, outsourcing relations develop slower than in medium and large enterprises. This makes the difference between Russian outsourcing and the Western analogues. For example, in Great Britain, most companies with small revenue use the accounting services of outsourcing companies. In Russia, involvement of small business in outsourcing is limited by the fact that small enterprises are either not interested in transparency of their reporting, or do not have possibility to perform analysis of practicability of transition the accounting to outsourcers.

Public authorities and government-owned corporations also do not use the advantages of outsourcing, though such organizations are the most active users of financial outsourcing services in the world. Necessity for saving budget funds, on the one hand, and constantly growing expenses for state machinery, on the other hand, require a completely new approach to costs reduction from bureaucrats. Besides significant saving of state funds, outsourcers can offer the simplification of document flow and share of liability, which is a very important argument for transfer of some financial tasks to specialized organizations.

The above mentioned factors influence the formation of tendencies of outsourcing development. In particular, during the future 2-3 years, it is expected that variety of large global outsourcing companies, like ADP - which has a branch in Poland - will enter the Russian market.

Entry of new large players into the market of financial outsourcing leads to rise of interest of industrial enterprises in the contractor's services; this tendency has been growing for several years not only in the capital but also in regions. Taking into account the growing demand in regions and necessity for reduction of costs, which outsourcing companies face due to increasing competition, it is possible to suppose that soon large providers of services will start opening their service centers in the regions.

\section{Conclusion}

Promotion of the idea of outsourcing in Russia requires a lot of effort. Even large players in the market of outsourcing cannot easily cope with this task, that's why there is a tendency among outsourcers to unite in order to exchange experience and create joint projects (Klimovets, 2015). Thus, in 2006 there appeared the Association of outsourcing companies which includes recognized leaders of outsourcing of various spheres: IBS (IT outsourcing), "KorpusGrup" (industrial and manufacturing outsourcing), Intercomp (financial outsourcing), Xerox (outsourcing of document flow), etc. The tasks of the Association in regard to business audience include distribution of knowledge about outsourcing and its types, achievement of understanding of processes of transition to outsourcing, and informing about development of the sphere and new services.

In order to attract attention of small entrepreneurship to financial outsourcing, the Moscow government and "Uchetniye Tsentry" ("Accounting Offices") LLC developed a project for creation of network of offices for accounting and audit for small enterprises. Methodical support will be provided by audit and consulting group "International taxation advisory and legal center". Our research shows the reasons for this project. In terms of expenses, it is not profitable for a small enterprise to keep the books for itself. Besides, CEO usually acquires a huge dependence on the chief accountant. At that, the specifics of activities of small enterprise supposes uneven burden on the chief accountant. Therefore, this project is the adaptation of the Western experience for the Russian reality.

\section{References}

Avdokushin E.F. (2007). Outsourcing of research and development, design and experimental operations in course of development of new world economy//Voprosy novoi ekonomiki. 2007. №4. P. 35-45.

Avdokushin E.F. (2005). International manufacturing - the foundation of new world economy//Mezhregionalnaya gruppa uchenykh institut problem novoi ekonomiki. 2005. №1. P. 3.

Klimovets M.V. (2010). Model for Evaluation of Financial Outsourcing Efficiency//Vestnik Finansovogo Universiteta. 2010. №1. P. 64-67

Klimovets O.V. (2006). Business process outsourcing under the conditions of "new economics" and competitive advantages development//lzvestiya Volgogradskogo gosudarstvennogo tekhnicheskogo universiteta. 2006. V.10. №5. P. 24-31.

Klimovets O.V. (2014). "Sochi-2014" as a public-private partnership project. In a digest: Society in the age of changes: development of new social and economic relations. Proceedings of V International research-to-practice conference. Saratov, 2014. P. 101-103

Klimovets O.V. (2014). Strategy of transborder organic growth of Russian companies//Sovremennie naukoemkie tekhnologii. 2014 . № 6. 
P. 71-72.

Klimovets O.V., Fundy K.V. (2014). Analysis of system development staff motivation hotels // Diskussia. 2014. № 8 (49). P. $97-102$.

Klimovets O.V., Fundy K.V. (2014). Theoretical and practical aspects of staff motivation system of hospitality industry companies // Ekonomika ustoichivogo razvitiya. 2014. № 3 (19). P. 110-115.

Klimovets O.V. (2013). Transnational corporations of Russia // Mezhdunarodny zhurnal eksperimentalnogo obrazovania. 2013. №5. P. 118-119.

Klimovets O.V., Klimovets M.V. (2013). Impact of the Olympics on the development of competitiveness of country and region. In digest: Nauka i obrazovanie v XXI veke. Proceedings of International science-to-practice conference: in 34 vol. 2013. P. 53-55.

Klimovets O.V. (2010). Shaping and development of Russian transnational corporations. Doctor of Economics thesis/Moscow State University named after M.V. Lomonosov. Moscow, 2010.

Klimovets O.V. (2015). Competitive advantages of petroleum exporting countries under volatility of prices for hydrocarbons // Mezhdunarodniy zhurnal eksperimentalnogo obrazovania. 2015. №3-3. P. 375-377.

Klimovets O.V. (2014). Marketing strategies of brand «SOCHI-2014» in post-Olympic period // Vestnik IMSIT. 2014. №3-4 (59-60). P. 35.

Klimovets M.V. (2015). Methodological basis for classification of outsourcing in international business// Mezhdunarodniy zhurnal eksperimentalnogo obrazovania. 2015. №3-3. P. 386-387.

Klimovets M.V. (2014). Outsourcing as a form of international business development in the globalized world // Economic Sciences. 2014. №12 (121). P. 151-153. 
